\title{
THE CORRELATION BETWEEN WORM INFECTIONS AND NUTRITIONAL STATUS AMONG ELEMENTARY SCHOOL STUDENTS
}

\author{
Liena Sofiana*, Erni Gustina, Yuniar Wardani, Suci Musvita Ayu, Aniq Diya \\ Nata Maula
}

Department of Public Health, Public Health Faculty, Universitas Ahmad Dahlan, Yogyakarta, Indonesia

*Correspondence: liena.sofiana@ikm.uad.ac.id. Telp.: +6285875555584

Received 07 August 2019; Accepted 09 September 2019; Published 09 September 2019

\begin{abstract}
Background: Worm disease is an infectious disease that still becomes a public health problem in Indonesia. Worm can cause a decrease in health, nutrition, intelligence and productivity of the sufferers. Worms as parasitic animals do not only take nutrients in the intestines of children, but they also damage the intestinal wall so that they interfere the absorption of these nutrients, consequently it will impact on the decreasing of one's nutritional status and cause other complex nutritional problems. Moyudan Health Center is a Community Health Center in Moyudan Sub-District Region which has the highest cases of helminthiasis (worm infection). Therefore, this study aims to determine the relationship between helminthiasis infection and nutritional status.

Methods: This was an observational analytic study by using a cross sectional approach. The sample of this study were elementary school students in the work area of Moyudan Health Center with samples of 311 respondents. The sampling technique used by multistage random sampling is the selection of samples consisting of the smallest areas of an area. Faecal examination was carried out by using the direct method and nutritional status assessment was carried out by anthropometric method based on the anthropometric index Body Age Index per Age (BMI / U). Data were analyzed by Fisher's test.

Results: The results showed that there were 8 respondents $(2.57 \%)$ who were positively infected by worms, 28 respondents had underweight nutritional status $(9.01 \%)$, and 54 respondents had a nutritional status of fat $(17.36 \%)$. The results of the study showed no correlation between helminthiasis infection and nutritional status ( $p$ value $=0.534)$.

Conclusions: There is no relationship between helminthiasis and nutritional status in elementary school students in the Moyudan Community Health Center Working Area in Sleman Regency with a $p$ value of 0.534 so that it is concluded that helminthiasis infection does not provide any significant contribution to nutritional status even though cases of helminthiasis still occur in elementary school students. Therefore, it needs more attention from parents, schools and health facilities in dealing with worm problems.
\end{abstract}

Keywords: Worm Infection, Nutritional Status, Elementary School Students 


\section{Epidemiology and Society Health Review $\mid \boldsymbol{E S H \boldsymbol { R }}$}

\section{INTRODUCTION}

Worm disease is an infectious disease that is still a public health problem in Indonesia because it spreads in most regions of Indonesia. Worm can cause health, nutrition, intelligence and productivity problems. Similarly, it can also cause loss of fat and protein and blood loss, thus reducing the quality of human resources (1). Worms are part of 17 Neglected Disease (NTD) (2). The most common types of worm that infect humans are Ascaris lumbricoides, Necator americanus, Ancylostoma duodenale, Trichuris trichiura, Strongyloides stercoralis, Trichinella spiralis and Enterobius vermicularis (3).

More than 1.5 billion people or $24 \%$ of the world's population are infected by earthworms that spread throughout the world. Infection is widespread in tropical and subtropical regions with the largest number occurring in Sub-Saharan, Africa, America, China and East Asia. More than 267 million preschoolers and more than 568 million school-aged children live in the area while these parasites are intensively transmitted and intervened. Therefore, treatment is immediately needed (4). The ones who often get infected are pre-schoolers, school-age children, women of childbearing age (including pregnant women in the second and third trimesters and breastfeeding), and adults with high-risk jobs such as tea pickers or miners are also vulnerable to worm infection (4). This disease generally attacks children because their resistance is still low. The factors that influence it are tropical condition, low awareness of cleanliness, poor sanitation, low socio-economic conditions, and population density (5).

Worms as parasitic animals do not only take nutrients in the child's intestine, but they also damage the intestinal wall so that they release these nutrients (6). Worms get food from tissues including proteins that will cause substances of protein and iron. Worms will also increase malabsorption nutrition. Some earthworms can also cause reduced appetite and therefore they can reduce nutritional intake and physical fitness (4).

The prevalence data of worm infection in 2016 in Sleman suggested that there were 559 cases of infection and the highest of all was found in Moyudan Community Health centre with 182 cases (7). Meanwhile, the screening data of students' weight and height from two elementary schools in Moyudan sub-district showed that 6 out of 170 students were categorized fat and 136 of them were normal. In addition, 12 students were thin and 16 were very thin. After studying the data, the researcher thinks that it is necessary to research this case further as it is important to know how big this case is and what efforts can be done to control and prevent this case.

\section{METHODS}

\section{Study design}

This research belongs to analytic observational research with cross sectional approach.

\section{Setting}

This research was conducted among the elementary students in the coverage area of Moyudan community health centre, Sleman, Yogyakarta. There were 21 elementary schools from 4 villages.

\section{Data source and data collection}

The data collection was done by measuring body weight and height to determine BMI (Body Mass Index) of students in the elementary schools. Meanwhile, the nutritional status was measured by using scales and microtoise. Worm examination was carried out with a direct method using a microscope conducted at the Moyudan Community Health Center laboratory. In addition, examination of the number of worm species in faecal samples was also carried out by counting the number of eggs, larvae or adult worms in the preparation.

\section{Sample population}

The research sample were elementary school students in the work area of Moyudan Health Center with a total of 311 samples. The school sampling technique was carried out by using probability sampling by means of multiple stage random sampling. 21 elementary schools from 4 villages were randomly selected and each of them had 3 primary schools which were sampled. Thus, the number of primary schools used was 12 schools which consists of grade 1 to grade 6 . The sample consists of 


\section{Epidemiology and Society Health Review $\mid \boldsymbol{E S H R}$}

286 people so that the total sample taken from each primary school were 24 people. Respondent samples were taken randomly by using simple random sampling.

\section{Variables}

The independent variable in this research was worm infection while the dependent variable was nutritional status of elementary school students.

\section{Analysis}

The analysis was done using chi square test with trust interval of $95 \%$. The value of $\alpha$ was 0.05 which also used fisher as its alternative. The requirement for chi square test is when there is no value of expected count below 5 or maximum $20 \%$ in cell.

\section{Ethical approval}

Number: 011804053

The ethical approval is based on ethical research committee of Universitas Ahmad Dahlan Yogyakarta.

\section{RESULTS}

Table 1. Respondent Distribution based on Gender and Age

\begin{tabular}{ccc}
\hline Variable & Frequency & Percentage (\%) \\
\hline Age (Year) & 1 & \\
5 & 8 & 0,3 \\
6 & 50 & 2,6 \\
7 & 64 & 16,1 \\
8 & 64 & 20,6 \\
9 & 53 & 20,6 \\
10 & 55 & 17,0 \\
11 & 15 & 17,7 \\
12 & 1 & 4,8 \\
13 & & 0,3 \\
Gender & 150 & \\
Male & 161 & 48,0 \\
Female & $\mathbf{3 1 1}$ & 52,0 \\
\hline Total & & $\mathbf{1 0 0 , 0}$
\end{tabular}

Source: Primary Data of 2018

Table 1 shows that the genders of the respondents are different. Male respondents consisted of 150 students $(48.23 \%)$ and female respondents are 161 students $(51.77 \%)$. In terms of age, the table shows that most of respondents are 8- and 9-years old totalling 64 students $(20.58 \%)$ while the least number is those aged between 5 to 13 years old accounting only 1 person $(0.32 \%)$. 


\section{Epidemiology and Society Health Review $\mid \boldsymbol{E S H \boldsymbol { R }}$}

Table 2. Worm Infections Distribution based on Gender

\begin{tabular}{|c|c|c|c|c|c|c|c|}
\hline \multirow{2}{*}{\multicolumn{2}{|c|}{ Variable }} & \multicolumn{4}{|c|}{ Gender } & \multirow{3}{*}{$\begin{array}{c}\text { Total } \\
\text { Number }\end{array}$} & \multirow{3}{*}{$\begin{array}{c}\text { Percentage } \\
(\%)\end{array}$} \\
\hline & & \multicolumn{2}{|r|}{ Male } & \multicolumn{2}{|c|}{ Female } & & \\
\hline & & Total & $\begin{array}{c}\text { Percentage } \\
(\%)\end{array}$ & Total & $\begin{array}{c}\text { Percentage } \\
(\%)\end{array}$ & & \\
\hline \multirow{3}{*}{$\begin{array}{l}\text { Worm } \\
\text { Infection }\end{array}$} & Positive & 6 & 1.93 & 2 & 0.64 & 8 & 2.57 \\
\hline & Negative & 144 & 46.30 & 159 & 51.13 & 303 & 97.43 \\
\hline & Total & 150 & 48.23 & 161 & 51.77 & 311 & 100.0 \\
\hline \multirow{4}{*}{$\begin{array}{l}\text { Nutritional } \\
\text { Status }\end{array}$} & Thin & 11 & 3.54 & 17 & 5.47 & 28 & 9.01 \\
\hline & Normal & 111 & 35.69 & 118 & 37.94 & 229 & 73.63 \\
\hline & Fat & 28 & 9.00 & 26 & 8.36 & 54 & 17.36 \\
\hline & Total & 150 & 48.23 & 161 & 51.77 & 311 & 100.0 \\
\hline
\end{tabular}

Source: Primary Data of 2018

Table 2 shows that most of respondents infected with helminthiasis were male with a total of 6 respondents, while female who were infected with helminthiasis were only 2 . Based on the nutritional status and sex of respondents, those with the lowest nutritional status were mostly female by $5.47 \%$. Respondents with the most normal nutritional status were also female by $37.94 \%$, while respondents with surplus nutritional status were more dominated by male, by $9 \%$.

Table 3. The Distribution of Worm Infection Based on Worm Type

\begin{tabular}{cccccc}
\hline \multirow{2}{*}{ Worm Type } & \multicolumn{2}{c}{ Gender } & Total & $\begin{array}{c}\text { Percentage } \\
\text { (\%) }\end{array}$ \\
\cline { 2 - 3 } & Male & Female & & 12.5 \\
Ascaris lumbricoides & 0 & 1 & 1 & 12.5 \\
Necator americanus & 1 & 0 & 1 & 25.0 \\
Ancylostoma duodenale & 2 & 0 & 2 & 37.5 \\
Enterobius vermicularis & 2 & 1 & 3 & 12.5 \\
Trichuris trichiura & 1 & 0 & 1 & $\mathbf{1 0 0 . 0}$ \\
\hline Total & $\mathbf{6}$ & $\mathbf{2}$ & $\mathbf{8}$ &
\end{tabular}

Source: Primary Data of 2018

Table 3 shows that of the 8 respondents who were positively infected with helminthiasis, in which most of them were infected with Enterobius vermicularis by $37.5 \%$ and Ancylostoma duodenale by $25 \%$. Other types of infecting worms were Ascaris lumbricoides, Necator americanus and Trichuris trichiura, by $12.5 \%$ consecutively.

Table 4. Fisher's test results between helminthiasis infection and nutritional status in elementary school students in the work area of Moyudan Public Health Center, Sleman

Regency

\begin{tabular}{cccccccccc}
\hline Variable & \multicolumn{4}{c}{ Nutritional Status } & \multicolumn{2}{c}{ Total } & \multirow{2}{*}{ RP } & \multirow{2}{*}{$\begin{array}{c}\text { W5\% } \\
\text { Worm }\end{array}$} & \multicolumn{2}{c}{ Thin } & \multicolumn{2}{c}{ Normal + Fat } & \multicolumn{2}{c}{$\begin{array}{c}\mathbf{P} \\
\text { Value } \\
\text { Infection }\end{array}$} & $\mathrm{n}$ & $\%$ & $\mathrm{n}$ & $\%$ & $\mathrm{n}$ & $\%$ & & & \\
\hline Positive & 1 & 0.3 & 7 & 2.3 & 8 & 2.6 & 1.403 & \multirow{2}{*}{$0.217-$} & \\
Negative & 27 & 8.7 & 276 & 88.7 & 303 & 97.4 & & \\
\hline Sum & $\mathbf{2 8}$ & $\mathbf{9 . 0}$ & $\mathbf{2 8 3}$ & $\mathbf{9 1 . 0}$ & $\mathbf{3 1 1}$ & $\mathbf{1 0 0}$ & & & \\
\hline
\end{tabular}

Table 4 shows that after cell merging and fisher test for a $2 \times 2$ table, it is found that there is 1 cell $(25 \%)$ that has an expected count value of less than 5 , so that the chi-square test requirements are not met. Therefore, fisher test was used as an alternative. From the results of the fisher test it was known that the $P$ value was 0.534 , which means that there was no relationship between helminthiasis infection and nutritional status of elementary school students in the work area of Moyudan Health 


\section{Epidemiology and Society Health Review $\mid \boldsymbol{E S H R}$}

Center, Sleman Regency. Fisher's test results also showed a value of Rp 1,403 with Confidence Interval of $95 \%(\mathrm{Cl}) 0.217-9,087$ which means that from the existing data it could not be concluded that helminthiasis could really become a risk factor that affects nutritional status.

\section{DISCUSSIONS}

The description of the respondents of the elementary school students in the work area of Moyudan Public Health Center Sleman Regency were mostly 8 and 9 years old with a percentage of $20.58 \%$ while the least were students aged 5 and 13 years with a percentage of $0.32 \%$. The percentage of female students was $51.77 \%$ which was greater than male students $(48.23 \%)$. The percentage of students infected with helminthiasis was $2.57 \%$, students with malnutrition status was $9.01 \%$, normal was $73.63 \%$ and fat was $17.36 \%$.

Based on table 5, it shows that out of 311 respondents there were $9.01 \%$ of respondents with malnutrition status, $17.36 \%$ of respondents were categorized fat while $73.63 \%$ of respondents were normal. From the results of this study it is known that there was more normal nutritional status than respondents who were thin and fat. Based on table 14, it is known that respondents with more or less nutritional status were experienced by respondents who were female and that is equal to $5.47 \%$. Meanwhile respondents with surplus nutritional status were more experienced by male respondents with a percentage of $9 \%$.

Worm disease is an endemic and chronic disease caused by worms with a high prevalence. It is however not lethal, but it risks the health of the human body resulting in a decrease in nutritional conditions and mostly attacks toddlers and children of primary school age (8). From the results of the study in table 3 it is known that out of 311 respondents there were 8 respondents who experienced helminthiasis or by $2.57 \%$. The results of the study shown in Table 4 indicate that helminthiasis experienced by respondents occurred due to infection from several types of worms, namely Ascaris lumbricoides by $12.5 \%$, Americanus by $12.5 \%$, Ancylostoma duodenale by $25 \%$, Trichuris trichiura by $12.5 \%$ and Enterobius vermicularis by $37.5 \%$.

Based on observations the low prevalence of helminthiasis could be caused by good behaviours that they had such as hand washing habits, defecation in the toilet, nails cutting once a week, fingernails biting prevention, and footwear using. This can also be a cause of low prevalence of worms. Behaviour had a relationship with infection with Soil Transmitted Helminth in students at Pertiwi Lamgarot Elementary School in Ingin Jaya District, Aceh Besar (9). The difference in the number of helminthiasis infections transmitted through soil can be influenced by differences in risk factors including geography and environment, community behaviour towards environmental sanitation and personal hygiene (10).

The results of this study also showed that of the 8 respondents who were positively infected with helminthiasis, there were 6 respondents who were male and 2 females. This is in line with the previous studies which said that male sex can be a risk factor for infection with helminthiasis (OR = 1.27). This can be due to the fact that a boy more often plays outside the house, so he interacts more frequently with the soil. Boys usually play soccer, play marbles or make toys from the ground (10).

Based on table 6, it is known that out of 8 respondents infected with worms, there were 1 respondent who had underweight nutritional status, 6 respondents had good nutritional status and 1 respondent had fat nutritional status. This is in line with previous studies which showed that respondents who were positively infected with helminthiasis with a status of malnutrition were less compared to students who experienced helminthiasis with a good nutritional status (8). Students with malnutrition status were $36.4 \%$ and $63.6 \%$ were nutritionally good. Previous research showed that there was no relationship between sex and nutritional status $(p$ value $=0.550)$.

The results of statistical tests using Fisher's test for $2 \times 2$ tables or after cell merging that can be seen in table 16 which shows that the relationship between helminthiasis infection and nutritional status in elementary school students in the Moyudan Health Center work area shows that statistically there was no significant relationship between infection with nutritional status ( $p$ value $=0.534$ ). The results 


\section{Epidemiology and Society Health Review $\mid \boldsymbol{E S H R}$}

of this study's test can be concluded that helminthiasis was a risk factor that affects nutritional status but was not statistically significant $(\mathrm{RP}=1,403,95 \% \mathrm{Cl}=0.217-9,087)$.

The absence of a relationship between helminthiasis infection and nutritional status in elementary school students in the working area of Moyudan Health Center Sleman Regency could be due to the low number of children infected with helminthiasis, this is supported by the finding of the previous studies that the low intensity of helminthiasis was a factor that caused the absence in the relationship between helminthiasis and nutritional status (11). Besides, a good environmental condition around might also contribute to this case where most of the respondents' homes had already have the availability of latrines in the category of fulfilling the conditions. In addition, the distance of the source of water from the disposal of faeces was $\geq 10 \mathrm{~m}$. moreover, most of the respondents' houses had used the type of floor that meets the requirements (12). Other studies also shown that many underweight children lived in slum areas with poor water sources, unhealthy latrines and poor sources of drinking water (13). The results of this study suggest that children who had poor nutritional status were not always due to helminthiasis infection, but there were other factors that affect the nutritional status. Previous research also shown the same thing that there was no relationship between helminthiasis infection and nutritional status based on BMI / $U$ in children in Barabai darat 2 Primary School with a value of $p$ value $=1,000$. The results of the study showed that there was no significant influence between helminthiasis infection and nutritional status. One reason was because it was not only an infection that could affect the state of human nutrition, but it could also be caused by many other factors. In addition, the process from helminthiasis to a decrease in nutritional status requires a certain period of time and with the severity of certain infections (14).

Theoretically, helminthiasis, which is one of the infectious diseases, is one of the direct causes that will affect one's nutritional status. This worm can lead to a decrease in the condition of health, nutrition, intelligence and productivity of the sufferer so that it causes many economic losses. Worms can cause loss of carbohydrates and proteins and blood, thus reducing the quality of human resources. Worms as parasitic animals do not only take nutrients in the child's intestine, but also damage the intestinal wall so that they disturb the absorption of these nutrients (6). Nutritional loss is calculated based on the behaviour of each species of worm which harms the sufferer (15).

Calculation of nutrient loss and economic loss in 3 worm species, namely Ascaris lumbricoides, Trichuris trichiura and Hookworm was done because these three species provide the greatest loss to sufferers. Food intake and infectious diseases are the direct causes of malnutrition (15). Nutritional and blood loss is likely to increase as the worm's intensity increases in the patient's body, the rapid development of worms requires immediate treatment to prevent new infections from occurring (2).

\section{CONCLUSIONS}

Based on the results of the research and discussion, it could be concluded that there is no correlation between helminthiasis infection and nutritional status in elementary school students in the Moyudan Health Center Working Area in Sleman Regency.

\section{AUTHORS' CONTRIBUTION}

All researchers contributed to conducting research ranging from surveys, data collection, data analysis to the preparation of research reports.

\section{FUNDING}

Institute for Research and Community Service.

\section{Acknowledgements}

The researcher would like to thank Universitas Ahmad Dahlan Yogyakarta for providing support and funding for this research. 


\section{Epidemiology and Society Health Review $\mid \boldsymbol{E S H R}$}

\section{Conflict of interest}

There are no conflicts of interest.

\section{REFERENCES}

1. Kementerian Kesehatan Republik Indonesia. Peraturan Menteri Kesehatan Republik Indonesia Nomor 15 Tahun 2017 Tentang Penanggulangan Kecacingan [Internet]. Jakarta; 2017 [cited 2018 Dec 28]. Available from: www.peraturan.go.id

2. Kesehatan BP dan P. Penyakit Menular Neglected Kajian Program dan Penelitian. Buku 1. Tjitra, Emiliana., Sudomo, Mohammad., Karyana M, editor. Jakarta: Kementerian Kesehatan Republik Indonesia; 2013. 43 p.

3. Sutanto I, Ismid I., Sjarifuddin P., Sungkar S. Buku Ajar Parasitologi Kedokteran. Jakarta: Balai Penerbit Fakultas Kedokteran Universitas Indonesia; 2009.

4. Organization WH. Soil-Transmitted Helminthiases: Eliminating Soil-Transmitted Helmnthiases as a Public Health Problem in Children [Internet]. Progress Report. France: World Health Organization; $2012 . \quad 1-90 \quad$ p. $\quad$ Available from: http://apps.who.int/iris/bitstream/handle/10665/44804/9789241503129_eng.pdf;jsessionid=08A 9C47002D754E4C5CD704D24C26420?sequence=1

5. Kementerian Kesehatan Republik Indonesia. Penyakit Kecacingan Masih Dianggap Sepele [Internet]. Kementerian Kesehatan Republik Indonesia. 2010 [cited 2018 Dec 28]. p. 1. Available from: http://www.depkes.go.id/article/print/1135/penyakit-kecacingan-masihdianggap-sepele.html

6. Kementerian Kesehatan Republik Indonesia. Pedoman Pengendalian Kecacingan. Jakarta: Kementerian Kesehatan Republik Indonesia; 2012. p. 1-48.

7. Dinas Kesehatan Kabupaten Sleman. Data Sekunder Dinas Kesehatan Kabupaten Sleman. Yogyakarta: Dinas Kesehatan Kabupaten Sleman; 2016.

8. M AR, Nelly M, Franly O. Hubungan Kecacingan Dengan Status Gizi Pada Murid Sekolah Dasar di Kabupaten Bolaang Mongondow Utara. Ejournal Keperawatan. 2013;1(1):1-6.

9. Rahmayanti, Razali, Mudatsir. Hubungan Pengetahuan, Sikap Dan Tindakan Dengan Infeksi Soil Transmitted Helminths (STH) Pada Murid Kelas 1, 2 dan 3 SDN Pertiwi Lamgarot Kecamatan Ingin Jaya Kabupaten Aceh Besar. J Biot [Internet]. 2014;2(hubungan pengetahuan,sikap, dan tindakan dengan infeksi soil transmitted helminths (STH) PADA MURID KELAS 1.2 dan 3 SDN PERTIWI LAMGAROT KECAMATAN INGIN JAYA KABUPATEN ACEH BESAR):77-137. Available from: https://jurnal.arraniry.ac.id/index.php/biotik/article/view/244

10. Sandy S, Sumarni S, Soeyoko. Analisis Model Faktor Risiko Yang Mempengaruhi Infeksi Kecacingan Yang Ditularkan Melalui Tanah Pada Siswa Sekolah Dasar di Distrik Arso Kabupaten Keerom, Papua. Media Litbangkes. 2015;25(1):1-14.

11. Kamila AD, Margawati A, Nuryanto. Hubungan Kecacingan dengan Status Gizi dan Prestasi Belajar pada Anak Sekolah Dasar Kelas IV dan VI di Kelurahan Bandarharjo Semarang. J Nutr Coll. 2018;7(2):77-83.

12. Mahmudah U. Hubungan Sanitasi Lingkungan Rumah Terhadap Kejadian Infeksi Kecacingan Pada Anak Sekolah Dasar. J Kesehat. 2017;10(1):32-9.

13. Suprapti, Hapsari D. Status Gizi Balita Berdasarkan Kondisi Lingkungan dan Status Ekonomi ( Data Riskesdas 2007 ). J Ekol Kesehat. 2007;10(2):103-13.

14. Azizaturridha A, Istiana, Hayatie L. Pengaruh infeksi kecacingan terhadap status gizi pada anak di SDN 2 Barabai Darat Kalimantan Selatan Tahun 2015. Berk Kedokt. 2016;12(2):16573.

15. Indriyati L, Waris L, Luciasari E. Kerugian Finansial Akibat Kecacingan: Studi di Kabupaten Nunukan. Penelit Gizi Makan. 2014;37(2):155-60. 
Epidemiology and Society Health Review $\mid \boldsymbol{E S H R}$ 